\title{
THEOLOGICAL DISCOURSE AND THEOLOGICAL TEXT IN PARADIGM OF MODERN LINGUISTIC RESEARCH
}

\section{Veresh M. T.}

\section{INTRODUCTION}

Communication is an essential part of today's society that takes place at many levels and in various spheres of human life. Therefore, discourse with all its elements is an important component of the communicative paradigm. The study of channels of communication as well as speech acts being the smallest component of discourse draws great attention from numerous scientists. Besides, due to the peculiarities of communication in this field the study of the theological discourse and its main constituent parts still holds the scholars' interest.

\section{The theological discourse and the speech act}

The concept of discourse does not replace the concept of text. Discourse presents a dimension much wider than text ${ }^{1}$. It denotes a complex communicative phenomenon that includes, in addition to text, extra-linguistic factors (knowledge of the world, views, directions, goals, addressees) necessary for text understanding ${ }^{2}$. N. D. Arutyunova shares the same opinion presenting the discourse as "a coherent text that includes extralinguistic, pragmatic, sociocultural, psycholinguistic and other factors; text viewed in the context $<\ldots>$, speech immersed in life" ${ }^{3}$. O.V. Yashenkova believes the discourse to be "a type of communicative activity, an interactive phenomenon, a speech stream that is reflected in different forms of expression (oral, written, paralingual). It occurs within a specific channel of communication (where the channel means a way of transmitting a message that takes into account human physiological capabilities). It is regulated by strategies and tactics of its participants, emerges as a synthesis of cognitive, linguistic, and extralinguistic factors that are determined by a specific circle of "life forms" dependent upon the topic of communication; and results in formation of various speech genres" 4 . The speech genre, in its turn, is the cognitive-pragmatic category of a discourse

${ }^{1}$ Корнейко I. В. Теорія жанру : теоретичні та прикладні аспекти : [монографія] / I. В. Корнейко, О. Б. Петрова, Н. О. Попова. - Харків : Друкарна Мадрид, 2014. - С. 6.

${ }^{2}$ Дейк Т. А. ван. Язык. Познание. Коммуникация / Т. А. ван Дейк. - М. : Прогресс, 1989. - С. 8 .

3 Лингвистический энциклопедический словарь [под ред. В. Н. Ярцева]. - М. : Советская энциклопедия, 1990. - С. 136-137.

${ }^{4}$ Яшенкова О. В. Основи теорії мовної комунікації : навч. посіб. / О. В. Яшенкова. К. : Академія, 2010. - С. 91. 
unit that exists in the linguistic consciousness of participants of communication, is verbally reproduced and recognized in speech, and also acts as a prerequisite for the mutual understanding 5 . Moreover, it contains a certain group of components including the communicative purpose, the image of the author, the nature of the addressee, and the language form ${ }^{6}$.

According to M.V. Shevchuk the speech genre acts as an interactive category of communicative discourse, which verbally (linguistic processing) manifests the intentions of the addressee in a particular situation of communication (dictum), taking into account the prerequisites and consequences of a communicative act (notions of communicative past and future), appeals to the consciousness, points of view, opinions of the addressee, and aims at realization of the meaningful communicative goal" ${ }^{\text {" }}$.

Speech genre acts as a connecting element between discourse and speech act, where the latter is the minimal interdependent unit of discourse that only gains its importance within the discourse. Speech act "as a unit of discourse is not limited to the speaker and his / her intentions, but rather presents the speech interaction of the speaker and the listener that is aimed at achieving perlocutive goals of the speaker with the help of constructing a discursive meaning in the process of communication" ${ }^{8}$.

Considering speech act within the frame of communicative-pragmatic paradigm, one of the main objects of which is the discourse, it is necessary to note that the scholars distinguish five classes of speech acts:

1) representatives (informative speech acts),

2) directives (speech acts resulting in action),

3) commissives (speech acts aimed at making commitments),

4) expressives (speech acts expressing the emotional state of the speaker)

5) declarations (speech acts declaring something) ${ }^{9}$.

${ }^{5}$ Шевчук М.В.Мовленнєвий жанр як категорія організації мовного коду в комунікативному дискурсі : [Електронний ресурс] / М. В. Шевчук // Науковий вісник Волинського національного університету ім. Лесі Українки. - 2009. - № 5. - С. 464-467 Режим доступу : http://www.nbuv.gov.ua/Portal/natural/nvvnu/filolog/2009_5/R7/Shevchuk.pdf.

6 Крылова О. А. Существует ли церквоно-религиозный функциональный стиль в современном русском литературном языке? / О. А. Крылова // Культурно-речевая ситуация в современной России. - Екатеринбург : Изд. Уральского ун-та, 2000. - С. 109.

${ }^{7}$ Шевчук М. В. Мовленнєвий жанр як категорія організації мовного коду в комунікативному дискурсі : [Електронний ресурс] / М. В. Шевчук // Науковий вісник Волинського національного університету ім. Лесі Українки. - 2009. - № 5. - С. 464-467. Режим доступу : http://www.nbuv.gov.ua/Portal/natural/nvvnu/filolog/2009_5/R7/Shevchuk.pdf.

${ }^{8}$ Яшенкова О. В. Основи теорії мовної комунікації : навч. посіб. / О. В. Яшенкова. К. : Академія, 2010. - С. 91-94.

${ }^{9}$ Searle J. A classification of illocutionary acts / J. R. Searle // Language in Society. London : Cambridge University Press, 1976. - № 5. - P. 10. 
Representatives refer to speech acts, which are characterized by original and consistent content, in particular, statement of facts, affirmation (such as truth - lie), descriptions and judgments ${ }^{10}$.

Human life is sacred because from its beginning it involves "the creative action of God" and it remains forever in a special relationship with the Creator, who is its sole end. God alone is the Lord of life from its beginning until its end: no one can, in any circumstance, claim for himself the right to destroy directly an innocent human being. Human procreation requires on the part of the spouses' responsible collaboration with the fruitful love of God; the gift of human life must be actualized in marriage through the specific and exclusive acts of husband and wife, following the laws inscribed in their persons and their union ${ }^{11}$.

Directives may be identified as the types of speech acts realized in speech in the form of offers, invitations, and requests ${ }^{12}$.

I address myself to you, Venerable Brothers in the Episcopate, who share with me the responsibility of safeguarding "sound teaching" (2 Tim 4:3), with the intention of clearly setting forth certain aspects of doctrine which are of crucial importance in facing what is certainly a genuine crisis, since the difficulties which it engenders have most serious implications for the moral life of the faithful and for communion in the Church, as well as for a just and fraternal social life ${ }^{13}$.

Commissives are speech acts required to perform certain actions or to make a speaker follow certain rules ${ }^{14}$.

"The transmission of human life is entrusted by nature to a personal and conscious act and as such is subject to the all-holy laws of God: immutable and inviolable laws which must be recognized and observed. For this reason, one cannot use means and follow methods which could be licit in the transmission of the life of plants and animals" ${ }^{15}$.

${ }^{10}$ Searle J. A classification of illocutionary acts / J. R. Searle // Language in Society. London : Cambridge University Press, 1976. - № 5. - P. 10.

${ }^{11}$ Donum vitae. Instruction on Respect for Human Life in its Origin and on the Dignity of the Human Procreation : [Електронний pecypc] - Режим доступу : http://www.vatican.va/ roman_curia/congregations/cfaith/documents/rc_con_cfaith_doc_19870222_respect-for-humanlife_en.html.

${ }^{12}$ Searle J. A classification of illocutionary acts / J. R. Searle // Language in Society. London : Cambridge University Press, 1976. - № 5. - P. 10.

13 John Paul II. Veritatis Splendor : [Електронний ресурс] - Режим доступу : http://w2.vatican.va/content/john-paul-ii/en/encyclicals/documents/hf_jp-ii_enc_06081993_ veritatis-splendor.html.

${ }^{14}$ Searle J. A classification of illocutionary acts / J. R. Searle // Language in Society. London : Cambridge University Press, 1976. - № 5. - P. 10.

${ }^{15}$ Donum vitae. Instruction on Respect for Human Life in its Origin and on the Dignity of the Human Procreation : [Електронний ресурс] - Режим доступу : http://www.vatican.va/ roman_curia/congregations/cfaith/documents/rc_con_cfaith_doc_19870222_respect-for-humanlife_en.html. 
Expressives may be understood as speech acts that express emotional state of the speaker: his attitude, mood, wishes, appraisal, etc. ${ }^{16}$.

However, the Church reaffirms her practice, which is based upon Sacred Scripture, of not admitting to Eucharistic Communion divorced persons who have remarried. They are unable to be admitted thereto from the fact that their state and condition of life objectively contradict that union of love between Christ and the Church, which is signified and effected by the Eucharist. Besides this, there is another special pastoral reason: if these people were admitted to the Eucharist, the faithful would be led into error and confusion regarding the Church's teaching about the indissolubility of marriage ${ }^{17}$.

\section{The theological discourse and the professional text}

Considering text as an element of discourse, it should be noted that in modern linguistic studies text is a subject to various scientific analysis and characterization of its various types. Such well-known linguists as R.-A. Beaugrande, I.R. Halperin, V.-U. Dressler, van Dijk, O.I. Moskalskaya, and G. Fater made an attempt to turn text into an object of linguistic studies and, thus, significantly contributed to the development of linguistics in the XX - XXI centuries. Discourse may also be viewed as an integral and cohesive text, the realization of which is determined by various socio-cultural factors. It reflects different language forms of expression as well as evaluative information (personal characteristics of the speakers, their background knowledge, communicative intentions) ${ }^{18}$. The communicative and pragmatic aspects indicate the dominant communicative function of the text, which determines the type of communicative contact with the help of which a speaker or a writer wants to express something to the listener or reader. The cognitive aspect, as a rule, is referred to the regular defined conditions of text understanding, which are defined by the linguistic act system. Besides, this aspect also includes prior knowledge used for the understanding of a particular text $^{19}$. For example, in a homily, as in a special type of linguistic communication in theology, it refers to "a specific communicative event that is

${ }^{16}$ Searle J. A classification of illocutionary acts / J. R. Searle // Language in Society. London : Cambridge University Press, 1976. - № 5. - P. 10.

17 John Paul II. Familiaris Consortio : [Електронний pecypc] - Режим доступу : http://w2.vatican.va/content/john-paul-ii/en/apost_exhortations/documents/hf_jp-ii_exh_ 19811122_familiaris-consortio.html.

${ }^{18}$ Комісар Л. П. Дискурс-аналіз як філософсько-методологічна стратегія в сучасних гуманітарних науках : [Електронний ресурс] / Л. П. Комісар // Вісник Національного авіаційного університету. Серія : Філософія. Культурологія. - 2012. - Вип. 1. - С. 21-25. Режим доступу до журналу : http://nbuv.gov.ua/j-pdf/Vnau_f_2012_1_7.pdf.

19 Beaugrande de R.-A. Einführung in die Textlinguistik / R.-A. de Beaugrande, W. U. Dressler. - Tübingen : Max Niemeyer Verlag, 1981. - S. 8. 
recorded in written texts and spoken language, and takes place in a specific, cognitive and typologically conditioned communicative space - discourse" ${ }^{20}$.

Dear Brothers and Sisters,

Six years ago we gathered in this Square to celebrate the funeral of Pope John Paul II. Our grief at his loss was deep, but even greater was our sense of an immense grace which embraced Rome and the whole world: a grace which was in some way the fruit of my beloved predecessor's entire life, and especially of his witness in suffering. $<\ldots>$ And now the longed-for day has come; it came quickly because this is what was pleasing to the Lord: John Paul II is blessed !<...>

Finally, on a more personal note, I would like to thank God for the gift of having worked for many years with Blessed Pope John Paul II. <...> Blessed are you, beloved Pope John Paul II, because you believed! Continue, we implore you, to sustain from heaven the faith of God's people. Amen ${ }^{21}$.

Text can be viewed both in terms of structural characteristics and in terms of semantics. According to L. Elmslev the structure may be presented as "an autonomous entity with internal dependencies. It doesn't denote a simple set of elements, but the integrity formed by interconnected and interdependent elements, and may preserve its form due to its relation to the other elements" ${ }^{22}$. Semantics denotes "all content and information transmitted in a language or any unit thereof" ${ }^{23}$. The analysis of the structure of a text shows the impossibility of separating it from the content, because the structure and semantics are closely linked. In terms of structural characteristics, the text focuses on the separability and linearity of its components. "The semantic characteristic of a text is its coherence" 24 . The semantic functions of grammatical means are used for the formation of thoughts and the transmission of meaningful expression. Structural functions "are not based on notional or conceptual content. <...> Structural functions assist shaping thoughts in communication. However, unlike semantic functions, they serve for this purpose not directly but indirectly, by participating in the establishment of those linguistic elements that act as transmitters of semantic content" ${ }^{25}$.

20 Чернявская В. Е. Лингвистика текста. Поликодовость, интертекстуальность, интердискурсивность : [учебное пособие] / В. Е. Чернявская.- М. : Либроком, 2009. - С. 143.

${ }^{21}$ Pope Benedict XVI . Homily: The Beatification of Pope John Paul II : [Електронний pecypc] - Режим доступу : https://www.ewtn.com/catholicism/library/homily-the-beatification-ofpope-john-paul-ii-6197.

С. 180. 23 Лингвистический энциклопедический словарь [под ред. В. Н. Ярцева]. - М. : Советская энциклопедия, 1990. - С. 435.

24 Шмелёва О. Ю. Терминологические процессы в диахронии и синхронии (на материале английского языка) / О. Ю. Шмелёва. - С-Пб. : СПбГУЭФ, 2010. - С. 118.

25 Бондарко А.В. Понятийные категории и языковые семантические функции в грамматике / А. В. Бондарко // Универсалии и типологические исследования : Мещаниновские чтения. - М. : Наука, 1974. - С. 61. 
According to V.E. Chernyavskaya, text is an important element of the communicative system that exists as a part of the system of discourse that is in the system of extratextual and extralinguistic background ${ }^{26}$. Text is a functional-semantic concept ${ }^{27}$. Text is non-autonomous and non-self-sufficient - it is the main but not the only component of textual (speech and mental) activity. Important components of this structure, in addition to text, are the author (sender), the reader (addressee), the reflected reality, and the linguistic system from which the author chooses the linguistic means enabling him to adequately embody his creative intent. Consequently, text is created to transfer the experience of objective-cognitive activity to a specific addressee, and therefore "always relates to the communicative situation and its anthropocenters: the author and the addressee, the subject of the speech and his communication partner" ${ }^{28}$. Text implements the specific communicative act of its author or authors. It is based on a certain communicative-pragmatic strategy or text function, which is manifested by the system of linguistic and contextual signals, which through formal expression imply an adequate response of the addressee ${ }^{29}$. The communication that takes place between the contact persons (those who speak and listen, those who write and read) takes place via text. Text is an operating unit of a language, and a sentence is its syntactic unit ${ }^{30}$. According to G. Vater, communication-oriented text linguistics considers the question of the purpose for which texts in communication (a communicative function of the text) may and should be used ${ }^{31}$. There is no clear answer to the question of what criteria the text should meet. O. Selivanova in her book "Modern Linguistics: A Terminological Encyclopedia" defines "two approaches to the differentiation of text categories: the first is based on the identification of a category of text as a basis for its creation, the second identifies text categories in already created texts" ${ }^{32}$. The main categories of text following scientist's work are cohesion, textuality, theme, informativeness, concept, and communicativeness. I.R. Halperin distinguishes ten text categories: informativeness, dividedness, prospection, retrospection, cohesion,

${ }^{26}$ Чернявская В. Е. Лингвистика текста. Поликодовость, интертекстуальность, интердискурсивность : [учебное пособие] / В. Е. Чернявская.- М. : Либроком, 2009. - С. 12.

${ }^{27}$ Halliday M. A. K. Explorations in the functions of language / M. A. K. Halliday. London : Edward Arnold, 1974. - P. 107.

28 Чернявская В. Е. Интерпретация научного текста / В. Е. Чернявская. - М. : КомКнига/ URSS, 2006. - С. 12.

${ }^{29}$ Гончарова Е. А. Интерпретация текста. Немецкий язык / Е. А. Гончарова, И. П. Шишкина. - М. : Высшая школа, 2005. - С. 8.

${ }^{30}$ Halliday M. A. K. Explorations in the functions of language / M. A. K. Halliday. London : Edward Arnold, 1974. - P. 107.

${ }^{31}$ Vater H. Einführung in dir Textlinguistik. Struktur, Thema und Referenz in Texten / H. Vater . - München, 1992. - S. 20-22.

${ }^{32}$ Селіванова О. Сучасна лінгвістика : термінологічна енциклопедія / О. Селіванова Полтава : Довкілля-К, 2006. - С.602. 
continuum, modality, autosemantics, completeness, and the subtext ${ }^{33}$. Whereas R.-A. Beaugrande and V.V. Dressler define only seven criteria: cohesion, coherence, intentionality, informativity, acceptability, situationality, intertextuality ${ }^{34}$. The categories that are characte-ristics of the professional texts are discussed in the following sections.

Reconsidering the problem of discourse and text communication, it should be noted that T.A. van Dijk says that discourse and text are interrelated as follows: "Discourse is text plus situation, and text is discourse minus situation” ${ }^{35}$. According to T.R. Kiyak this relation may be presented as follow: "discourse $=$ text + context". The latter includes lingual and extralingual parameters" ${ }^{36}$.

Due to the diversity of human activities discourse, as a process of linguistic communication that unfolds in time and space, occurs through a specific language, is combined with specific mental, cognitive, social, and other actions and states, and is accompanied by interaction with various sub-objects and objects, becomes a rather many-branched system. Constantly expanding, it is trying to reach more and more varieties of vocational-oriented communication. Researchers distinguish pedagogical, scientific, political, everyday, religious discourses, etc. ${ }^{37}$. Religious discourse is the subject of our study. It is presented as a specific type of communication inherent to the church as an institution that contains all the peculiarities of communication in such an environment $^{38}$. A.K. Salakhova expands the definition and believes that religious discourse is a set of oral and written texts that serve for communication within the church and contain such features as: a hierarchy of communicators, a certain chronotype (relationship of time and space), the corresponding values and norms of religious communications, clear goals and appropriate strategies ${ }^{39}$.

33 Гальперин И. Р. Текст как объект лингвистического исследования / Гальперин И. Р. - М. : Наука, 1981. - С. 27.

34 Beaugrande de R.-A. Einführung in die Textlinguistik / R.-A. de Beaugrande, W. U. Dressler. - Tübingen : Max Niemeyer Verlag, 1981. - S. 3ff.

35 Дейк Т. А. ван. Язык. Познание. Коммуникация / Т. А. ван Дейк. - М. : Прогресс, 1989. - С. 87.

36 Кияк Т. Р. Міжкультурана комунікація, дискурс та переклад / Тарас Кияк // Актуальні питання іноземної філології : наук. журн. / [редкол. : І. П. Біскуб та ін.]. - Луцьк : Східноєвроп. нац. ун-т ім. Лесі Українки, 2015. - № 2. - С. 86.

${ }^{37}$ Яшенкова О. В. Основи теорії мовної комунікації : навч. посіб. / О. В. Яшенкова. К. : Академія, 2010. - С. 90-94.

${ }^{38}$ Карасик В. И. Языковой круг : личность, концепты, дискурс / В. И. Карасик. Волгоград : Перемена, 2002. - С. 65.

39 Салахова А. Г. Стратегия аргументации в религиозном Интернет-дискурсе / А. Г. Салахова // Вестник Челябинского государственного университета. Серия : Филология. Искусствоведение. - Челябинск : Челябинск. гос. университет, 2010. - Вып. 49. № 34 (215). - C. 109. 
Religious discourse is realized through three dimensions: in the temple (prayer, worship, communions), outside the temple (teaching in theological seminaries and theological faculties, speaking at theological conferences, classes on religion in schools) and in a secular environment (appearances in mass media) ${ }^{40}$. The strategies of religious discourse include prayer and confessional strategies, self-identification strategies, explanatory, evaluative, invocative, ritual, strategies for forcing emotional $\operatorname{mood}^{41}$. Religious discourse represents a broader sphere of communication that does not require specialized knowledge, unlike theology, which can be viewed as a separate discourse. We believe that it is also important to distinguish the theological seminary and theological faculties, appearances at theological conferences in a separate discourse of theology. Theological discourse is clearly related to theology as a science, and includes, in addition to a professional theological text, extra-lingual factors. They are knowledge of God and Divine Revelation. Theological discourse has communication participants - addressees theologians, priests, representatives of the church hierarchy, as well as believers, contains guidance on spiritual and moral life based on Scripture, Divine Revelation and the tradition of the Church. It has an oral and written form of manifestation and takes place within specific channels of communication: praying, theological conferences, lectures at theological faculties, teaching in theological seminaries.

Theological discourse is also governed by specific strategies. Taking into account the typology of communicative strategies based on groups of speech acts and united by similar communicative functions proposed by T. Tolmachova ${ }^{42}$, the strategies of theological discourse include informative and communicative, that contains a set of speech acts, whose main task is to present and receive information. In theological discourse, this is primarily the matter of faith. At the level of speech acts, it is mostly through representations that express truth and consistency.

This catechism aims at presenting an organic synthesis of the essential and fundamental contents of Catholic doctrine, as regards both faith and morals, in the light of the Second Vatican Council and the whole of the Church's Tradition. Its principal sources are the Sacred Scriptures, the Fathers of the Church, the liturgy, and the Church's Magisterium. It is intended to serve

40 Салахова А. Г. Стратегия аргументации в религиозном Интернет-дискурсе / А. Г. Салахова // Вестник Челябинского государственного университета. Серия : Филология. Искусствоведение. - Челябинск : Челябинск. гос. университет, 2010. - Вып. 49. № 34 (215). - C. 109.

${ }^{41}$ Яшенкова О. В. Основи теорії мовної комунікації : навч. посіб. / О. В. Яшенкова. К. : Академія, 2010. - С. 166.

${ }^{42}$ Толмачева Т. А. Методический потенциал использования коммуникативных стратегий иноязычного речового поведения в процессе обучения иностранному языку в языковом вузе / Т. А. Толмачева // Мир науки, культур, образования. - 2008. - № 4 (11). - С. 96. 
"as a point of reference for the catechisms or compendia that are composed in the various countries" $" 43$.

The discourse of theology can also serve as an emotion-regulation and regulatory-stimulating communication strategy. The emotional state of the interlocutor is expressed with the help of an emotion-regulation strategy, and the direct motivation to act with the help of the regulatory and stimulating. It is realized with the help of expressives, directives, and commissives.

I ask everyone to look more deeply at man, whom Christ has saved in the mystery of his love, and at the human being's unceasing search for truth and meaning. Different philosophical systems have lured people into believing that they are their own absolute master, able to decide their own destiny and future in complete autonomy, trusting only in themselves and their own powers. But this can never be the grandeur of the human being, who can find fulfilment only in choosing to enter the truth, to make a home under the shade of Wisdom and dwell there. Only within this horizon of truth will people understand their freedom in its fullness and their call to know and love God as the supreme realization of their true self $f^{44}$.

It is also expressed in prayers.

Volk: The offering of peace, the sacrifice of praise!

Priest: The grace of our Lord Jesus Christ and the love of God and Father and the communion in the Holy Spirit, be with all of you.

Volk: And with your spirit.

Priest: Let us lift up or hearts!

Volk: We have lifted them up to the Lord.

Priest: Let us give thanks to the Lord.

Volk: It is proper and just to worship the Father and the Son and the Holy Spirit, the Trinity, one in substance and undivided ${ }^{45}$.

The prayer and confessional strategies may also be included in the strategies of theological discourse mentioned above, though they may belong to both religious and theological discourse since discourses can be intertwined. The prayer strategy is first and foremost a sincere appeal to God. Prayer is the coming of the soul to God or asking God for appropriate benefits ${ }^{46}$. A prayer strategy that is implemented through the tactics of exaltation, repentance, supplication, and thanksgiving can also be associated with the recognition of faith.

${ }^{43}$ Catechism of the Catholic Church : [Електронний ресурс] - Режим доступу : http://www.vatican.va/archive/ENG0015/INDEX.HTM.

${ }^{44}$ John Paul II. Fides et ratio. - [Електронний ресурс]. - Режим доступу : http://w2.vatican.va/content/john-paul-ii/en/encyclicals/documents/hf_jp-ii_enc_14091998_ fides-et-ratio.html.

${ }^{45}$ Byzantine Book of Prayer. - Byzantine Seminary Press, 1995. - P. 149.

46 Иоанн Дамаскин Св. Точное изложение православной веры / Св. Иоанн Дамаскин. - М. , 2000. - С. 263. 
I believe in one God, the Father Almighty, creator of heaven and earth and of all things visible and invisible; and in one Lord, Jesus Christ, Son of God, the only begotten, born of the Father before all ages, Light of Light, true God of true God, begotten, not made of one substance with the Father and trough whom all things were made. $<\ldots>$ I believe in one, holy catholic and apostolic Church. I profess one baptism for the remission of sins. I expect the resurrection of the dead and the life of the world to come. Amen ${ }^{47}$.

Unlike the prayer strategy, the prescriptive strategy involves the presence of a priest, since "confession occurs in front of a priest who is a witness of the sinner's repentance and mediator of God's forgiveness" 48 . "Know that Christ himself, our Savior, who knows all the secrets of the secret" of human hearts, is invisibly present, receiving your confession" ${ }^{49}$. Confessional and prayer strategies are related, as you need to prepare for the confession. Important conditions are sincere repentance, reconciliation with one's neighbour. Having begun confession, sincerely confessing to the priest all sins, the person accepts the confession of the confessor, imposed redemption and resolution ${ }^{50}$. Consequently, the following tactics can be distinguished in a confessional strategy: the examination of conscience, repentance, reconciliation, teaching, repentance, and resolution. By combining all the sacraments into one confessional strategy, one can distinguish a sacramental strategy, which includes the prayer, in addition to the seven sacraments, as it is done in worship through prayer. Within the theological discourse and the framework of a regulatory-compulsory communication strategy aimed at controlling the behaviour of the speaker, one may distinguish a decalogue strategy that compels the communication participant to perform certain actions: keeping the Ten Commandments of God:

1. I am the Lord your God, you shall not have strange gods before Me.

2. You shall not take the name of the Lord your God in vain.

3. Remember to keep holy the Lord's day.

4. Honor your father and mother.

5. You shall not kill.

6. You shall not commit adultery.

7. You shall not steal.

8. You shall not bear false witness against thy neighbour.

9. You shall not covet your neighbour's wife.

${ }^{47}$ Byzantine Book of Prayer. - Byzantine Seminary Press, 1995. - P. 10-11.

${ }^{48}$ Катехизм Української Греко-Католицької Церкви : Христос - наша Пасха. - Львів : Свічадо, 2011. - С. 150.

${ }^{49}$ Прийдіте поклонімося. Молитовник. - Львів : Свічадо, 2008. - 988 с.

${ }^{50}$ Катехизм Української Греко-Католицької Церкви : Христос - наша Пасха. - Львів : Свічадо, 2011. - С. 151. 
10. You shall not covet thy neighbour's goods ${ }^{51}$. tactics.

and perfecting in God's and moral virtues that can be perceived as

"Four virtues play a pivotal role and accordingly are called "cardinal", all the others are grouped around them. They are: prudence, justice, fortitude, and temperance ${ }^{52}$.

It should also be mentioned that discourse and terminology are interconnected through the term because in the process of professional communication (communication) it "remains the main and dominant unit" ${ }^{53}$. In professional communication and the terminological system, a term is a basic unit. If professional language, as the set of all language means for communication in the professional field, is included in the professional discourse, and the terminology ensures the clear functioning of the professional language, then these three elements are also interrelated.

The same principle may be applied to the terminology we are studying, considering that professional communication in the field of theology is provided by the language means of the professional language of theology, which, in turn, uses the terms of the theological terminology system: professional communication in the field of theology $\rightarrow$ the special language of theology $\rightarrow$ theological terminology.

The main components of professional communication are the producer (written or oral) of the professional text, the professional text and its recipient ${ }^{54}$. The difference between text and professional text is emphasized by R. Glazer, who states that "text is the result of a mental-lingual treatment of a conventional object according to the conventionalized sample, and a professional text is a result of mental-lingual processing of a specific object according to a conventional pattern" ${ }^{55}$. K.-D. Baumann considers the professional text as "a complex unit, which, on the one hand, consists of social, situational and thematic factors, and on the other, is made with the help of text-structural, stylistic and formal properties" 56 . "Professional text as a result of the communicative activity is a coherent, logically structured, complete complex

${ }^{51}$ Catechism of the Catholic Church : [Електронний ресурс] - Режим доступу : http://www.vatican.va/archive/ccc_css/archive/catechism/command.htm.

${ }^{52}$ Catechism of the Catholic Church : [Електронний ресурс] - Режим доступу : http://www.vatican.va/archive/ccc_css/archive/catechism/p3s1c1a7.htm.

${ }^{53}$ Акимова О. В. Типология дискурса в професиональной коммуникации / О. В. Акимова, М. И. Солнышкина // Актуальные проблемы теории коммуникации. Сборник научных трудов. - С-Пб. : СПбГПУ, 2004. - С. 253 -270. : [Електронний ресурс]. - Режим доступу : http://www.russcomm.ru/rca_biblio/a/akimova-solnishkina.html.

${ }^{54}$ Roelcke T. Fachsprachen / T. Roelcke - Berlin: Erich Schmidt Verlag, 2005. - S. 54. 1990. - S. 18.

55 Gläser R. Fachtextsorten im Englischen / Rosemarie Gläser. - Tübingen,

${ }^{56}$ Baumann K.-D. Integrative Fachtextlinguistik / K.-D. Baumann. - [Forum für Fachsprachen-Forschung 18]. - Tübingen, 1992. - S. 9. 
statement that describes a specific subject for a particular profession with the help of various linguistic means and may be supplemented by visual means such as symbols, formulas, equations, graphs, drawings, etc. ${ }^{57}$.

The basis of the professional text is terminological vocabulary, which is the object of study of terminology as a science of professional concepts and their nominations in professional languages ${ }^{58}$. The relationship between professional communication in theology and the components of professional communication, in particular, the term (term as an element of the system and the object of our study) can be schematically presented as follows:

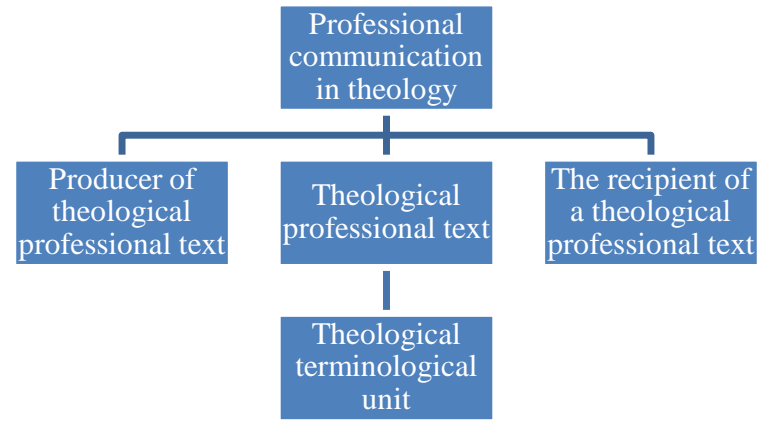

Fig. 4. Connection between professional communication and terminological vocabulary

Following the schematic representation given above, we may conclude that professional communication in theology is based on several interrelated elements that have a professional orientation in its core. The term is the smallest element of this type of communication, without which a professional orientation would not be possible.

\section{CONCLUSIONS}

Thus, as a result of a thorough analysis of the concepts of discourse and text in paradigms of modern linguistic research, we may conclude that professional communication in the field of theology is provided by the theological discourse. This discourse contains the theological professional text and extralinguistic factors along with the strategies and tactics of the theological discourse serving its various purposes. The dominant units of professional communication within theology are the theological terms that are the elements of the professional text.

${ }^{57}$ Gläser R. Fachtextsorten im Englischen / Rosemarie Gläser. - Tübingen, 1990. - S. 18.

${ }^{58}$ Міщенко А. Л. Лінгвістика фахових мов та сучасна модель науково-технічного перекладу : монографія / А. Л. Міщенко. - Вінниця : Нова Книга, 2013. - С. 163. 


\section{SUMMARY}

Professional communication in theology takes place within the discourse of theology, which is intertwoven with religious discourse.

Such types of speech acts as representatives, directives, commissives, expressives, and declarations bear great significance in theological discourse and are reflected at different levels of expression.

Elements of theological discourse are professional theological texts and extralinguistic factors. The theological discourse contains instructions for the spiritual and moral life based on the Holy Scriptures, Divine Revelation and the Tradition of the Church. There are oral and written forms that occur within specific channels of communication. The discourse of theology is regulated by specific strategies: profession of faith (tactics: belief in one God, the dogmas of the Church, the truth of faith); prayer (the tactics of praise, confession, thanksgiving, request); Sacraments (tactics: the life in God through the Sacraments); Decalogue (tactics: observance of the Ten Commandments of God, the perfection of moral and theological virtues).

\section{REFERENCES}

1. Акимова О.В. Типология дискурса в професиональной коммуникации / О.В. Акимова, М. И. Солнышкина // Актуальные проблемы теории коммуникации. Сборник научных трудов. - С-Пб. : СПбГПУ, 2004. - С. 253-270. : [Електронний ресурс]. - Режим доступу : http://www.russcomm.ru/rca_biblio/a/akimova-solnishkina.html.

2. Бондарко А. В. Понятийные категории и языковые семантические функции в грамматике / А. В. Бондарко // Универсалии и типологические исследования : Мещаниновские чтения. - М. : Наука, 1974. - C. 5-79.

3. Гальперин И. Р. Текст как объект лингвистического исследования / Гальперин И. Р. - М. : Наука, 1981. - 140 с.

4. Гончарова Е. А. Интерпретация текста. Немецкий язык / Е. А. Гончарова, И. П. Шишкина. - М. : Высшая школа, 2005. - 368 с.

5. Дейк Т. А. ван. Язык. Познание. Коммуникация / Т. А. ван Дейк. - М. : Прогресс, 1989. - 311 с.

6. Ельмслев Л. Пролегомены к теории языка / Л. Ельмслев. - М. : КомКнига, 2006. - 248 с.

7. Иоанн Дамаскин Св. Точное изложение православной веры / Св. Иоанн Дамаскин. - М. , 2000. - 463 с.

8. Карасик В. И. Языковой круг : личность, концепты, дискурс / В. И. Карасик. - Волгоград : Перемена, 2002. - 477 с.

9. Катехизм Української Греко-Католицької Церкви : Христос наша Пасха. - Львів : Свічадо, 2011. - 336 с.

10. Кияк Т. Р. Міжкультурана комунікація, дискурс та переклад / Тарас Кияк // Актуальні питання іноземної філології : наук. журн. / 
[редкол. : І. П. Біскуб та ін.]. - Луцьк : Східноєвроп. нац. ун-т ім. Лесі Українки, 2015. - № 2. - С. 83-89.

11. Комісар Л. П. Дискурс-аналіз як філософсько-методологічна стратегія в сучасних гуманітарних науках : [Електронний ресурс] / Л. П. Комісар // Вісник Національного авіаційного університету. Серія : Філософія. Культурологія. - 2012. - Вип. 1. - С. 21-25. - Режим доступу до журналу : http://nbuv.gov.ua/j-pdf/Vnau_f_2012_1_7.pdf.

12. Корнейко I. В. Теорія жанру : теоретичні та прикладні аспекти : [монографія] / I. В. Корнейко, О. Б. Петрова, Н. О. Попова. - Харків : Друкарна Мадрид, 2014. - 127 с.

13. Крылова О. А. Существует ли церквоно-религиозный функциональный стиль в современном русском литературном языке? / О. А. Крылова // Культурно-речевая ситуация в современной России. Екатеринбург : Изд. Уральского ун-та, 2000. - С. 107-119.

14. Лингвистический энциклопедический словарь [под ред. В. Н. Ярцева]. - М. : Советская энциклопедия, 1990. - С. 685.

15. Міщенко А. Л. Лінгвістика фахових мов та сучасна модель науково-технічного перекладу : монографія / А. Л. Міщенко. - Вінниця : Нова Книга, 2013. - 448 с.

16. Прийдіте поклонімося. Молитовник. - Львів : Свічадо, 2008. $988 \mathrm{c}$.

17. Салахова А. Г. Стратегия аргументации в религиозном Интернет-дискурсе / А. Г. Салахова // Вестник Челябинского государственного университета. Серия: Филология. Искусствоведение. - Челябинск : Челябинск. гос. университет, 2010. - Вып. 49. - № 34 (215). - С. 109-112.

18. Селіванова О. Сучасна лінгвістика : термінологічна енциклопедія / О. Селіванова - Полтава : Довкілля-К, 2006. - 716 с.

19. Толмачева Т. А. Методический потенциал использования коммуникативных стратегий иноязычного речового поведения в процессе обучения иностранному языку в языковом вузе / Т. А. Толмачева // Мир науки, культур, образования. - 2008. - № 4 (11). - С. 95-98.

20. Чернявская В. Е. Интерпретация научного текста / В. Е. Чернявская. - М. : КомКнига/ URSS, 2006. - 126 с.

21. Чернявская В. Е. Лингвистика текста. Поликодовость, интертекстуальность, интердискурсивность : [учебное пособие] / В. Е. Чернявская.- М. : Либроком, 2009. - 248 с.

22. Шевчук М. В. Мовленнєвий жанр як категорія організації мовного коду в комунікативному дискурсі : [Електронний ресурс] / M. В. Шевчук // Науковий вісник Волинського національного університету ім. Лесі Українки. - 2009. - № 5. - С. 464-467-Режим доступу : http://www.nbuv.gov.ua/Portal/natural/nvvnu/filolog/2009_5/ R7/Shevchuk.pdf. 
23. Шмелёва О. Ю. Терминологические процессы в диахронии и синхронии (на материале английского языка) / О. Ю. Шмелёва. - С-Пб. : СПбГУЭФ, 2010. - 120 с.

24. Яшенкова О. В. Основи теорії мовної комунікації : навч. посіб. / О. В. Яшенкова. - К. : Академія, 2010. - 312 с.

25. Baumann K.-D. Integrative Fachtextlinguistik / K.-D. Baumann. [Forum für Fachsprachen-Forschung 18]. - Tübingen, 1992. - 266 S.

26. Beaugrande de R.-A. Einführung in die Textlinguistik / R.-A. de Beaugrande, W. U. Dressler. - Tübingen : Max Niemeyer Verlag, 1981. - 215 S.

27. Byzantine Book of Prayer. - Byzantine Seminary Press, 1995. - 623 p.

28. Catechism of the Catholic Church : [Електронний ресурс] - Режим доступу : http://www.vatican.va/archive/ENG0015/_INDEX.HTM.

29. Catechism of the Catholic Church : [Електронний ресурс] - Режим доступу http://www.vatican.va/archive/ccc_css/archive/catechism/command.htm.

30. Catechism of the Catholic Church : [Електронний ресурс] Режим доступу : http://www.vatican.va/archive/ccc_css/archive/catechism/ p3s1c1a7.htm.

31. Donum vitae. Instruction on Respect for Human Life in its Origin and on the Dignity of the Human Procreation : [Електронний ресурс] Режим доступу : http://www.vatican.va/roman_curia/congregations/cfaith/ documents/rc_con_cfaith_doc_19870222_respect-for-human-life_en.html.

32. Gläser R. Fachtextsorten im Englischen / Rosemarie Gläser. Tübingen, 1990. - $331 \mathrm{~S}$.

33. Halliday M. A. K. Explorations in the functions of language / M. A. K. Halliday. - London : Edward Arnold, 1974. - 143 p.

34. John Paul II. Familiaris Consortio : [Електронний ресурс] - Режим доступу : http://w2.vatican.va/content/john-paul-ii/en/apost_exhortations/ documents/hf_jp-ii_exh_19811122_familiaris-consortio.html.

35. John Paul II. Fides et ratio. - [Електронний ресурс]. - Режим доступу : http://w2.vatican.va/content/john-paul-ii/en/encyclicals/documents/ hf_jp-ii_enc_14091998_fides-et-ratio.html.

36. John Paul II. Veritatis Splendor : [Електронний ресурс] - Режим доступу : http://w2.vatican.va/content/john-paul-ii/en/encyclicals/documents/ hf_jp-ii_enc_06081993_veritatis-splendor.html.

37. Pope Benedict XVI . Homily: The Beatification of Pope John Paul II : [Електронний ресурс] - Режим доступу : https://www.ewtn.com/catholicism/ library/homily-the-beatification-of-pope-john-paul-ii-6197.

38. Roelcke T. Fachsprachen / T. Roelcke - Berlin: Erich Schmidt Verlag, 2005. - 253 S. 
39. Searle J. A classification of illocutionary acts / J. R. Searle // Language in Society. - London : Cambridge University Press, 1976. - № 5. Pp. 1-23.

40. Vater H. Einführung in dir Textlinguistik. Struktur, Thema und Referenz in Texten / H. Vater . - München, 1992. - 199 S.

Information about the author:

Veresh M. T.,

$\mathrm{PhD}$ in Germanic Languages, Associate Professor at the Faculty of Foreign Philology, Department of German Philology

Uzhhorod National University 3, Narodna Sq., 88000, Uzhhorod, Ukraine 